\title{
THE DEVELOPMENT OF ISLAM IN THE KUBU KINGDOM (1768 - 1944)
}

\author{
Erwin Mahrus \\ Pontianak State College of Islamic Studies
}

\begin{abstract}
The origin of the Kubu Kingdom was previously marked with the establishment of a village at the junction of three rivers and the construction of a fort in 1768. In other words, Kubu was a checkpoint to secure the waters from pirate attacks (Djunaidy, 2001). The new village was officially named "Kubu" in 1775 (Yosep, 1995). Later on, it became a kingdom because of the massive migration into the new territory. They embraced Islam and made it an Islamic Kingdom in West Borneo. The territory of Kubu Kingdom was very limited merely to include Padang Tikar, Terentang, Kubu, and Teluk Pekadai. Originally this area was empty. It means that the Kubu Kingdom initially did not consist of densely populated villages. As a new region, it is thought that the establishment of this Kingdom coincided with the advent of Islam brought by Syarif Idrus Alaydrus. Thus, there have been long dynamics of Islamization in this Kingdom, and reached its peak when Syarif Abbas was in power. During his reign, the institution of the mufti was created and a number of religious works were written. This paper looks at the process of early entry and development of Islam in the Kubu Kingdom, its religious scholars and their works as well as its religious institutions that once existed in the Kingdom.
\end{abstract}

Keywords: Islam, Kubu Kingdom, religious works and religious institutions

\section{INTRODUCTION: THE PROCESS OF ENTRY AND SPREAD OF IS- LAM IN THE KUBU KINGDOM}

The process of Islamization that took place in the Kubu Kingdom can be explain using the following theories: first, the arrival. Second, the spread. Third, its institutionalization. At this stage of the arrival of Islam in this region was in conjunction with the opening of the village of Olak-Olak Kubu and continued to the Terentang River by Syarif Idrus (see Syarif Abdullah, 1937). Syarif Idrus indeed established a village at the junction of three rivers, but he still lived in the region of Dabung. Islam was present in this region but not yet spread intensively. In addition, the activities of piracy carried out by pirates (lanun) made Syarif Idrus pay more attention to efforts in maintaining the security of the waters of this region.

The spread was effective when this village was inhabited by many residents and officially became Kubu village in 1775 . Syarif. Idrus was a muballigh (preacher) 
played an important role in the spread of Islam (see manuscript of the genealogy of Muballigh in Indonesia, tt.). After a five-year process of the spread of Islam, about 1780, Islam began to enter the stage of institutionalization marked by the establishment of the Kubu Kingdom and the ascension of the Syarif Idrus Alaydrus as the first King with the title of Tuan Besar Raja Kubu (Lord of the King of Kubu. With the establishment of the Kingdom, the position of Islam was increasingly well-established and the number of believers had increased. Here goes the theory put forward by Ibnu Khaldun, al-nas 'ala din al-malik that people follow the religion of their King (see Ibn Khaldun, 1967)

To support the activities of Islamization, a surau (smaller mosque) was built which now sits next to the cemetery complex of Syarif Idrus. Based on its functions, in addition to serving as a place of worship, the surau also became the center of Islamic learning. There is no information that mentions the names of scholars who taught the religion of Islam when Syarif Idrus was in power. However, the name of one of his ministers, Sheikh Ahmad Fallugah (see Syarif Saleh, tt.) might have been a cleric who assisted Tuan Besar Raja Kubu in handling the Islamic religious affairs in the Kingdom. The fact that Ahmad Fallugah was an ulama (Islamic cleric) can be traced for example from the title 'Sheikh' in front of his name.

The institutionalization of Islam reached its peak during Syarif Abbas Alaydrus' reign (1900-1911) which was marked by the creation of the institution of the mufti (a scholar with the authority to issue legal opinions, or fatwa, on Islamic law) and appointed Ismail Mundu as his mufti in 1907. The existence of this institution opened the opportunities for the development of Islam in the Kingdom as it will appear in the next discussion. Islam became the religion of the Kingdom and the rest of the policy should be based on the teachings of Islam.

Based on a variety of historical data successfully collected, it can be classified that there are various ways of the Islamization in the Kubu Kingdom. The classification made was based more on criteria of activities and forum, or tools and media used in the activity of Islamization. The classification is not absolute, meaning that a preacher could have used more than one way of Islamization.

Several methods used in the process of Islamization are among others: (1) preaching by Muslim immigrants (2) education (3) writing and translating books, (4) using the mass media.

\section{Da'wah through Muslim immigrants}

The da'wah (preaching of Islam) here was intended as one of the activities to 
spread knowledge of Islamic teachings conducted by the Muslim immigrants, especially those from the Middle East. In fact, in the past, the arrival of these immigrants was related to trade activities, but often they also simultaneously became a $d a^{\prime} i$ (a preacher) who was instrumental in the spread of Islam. In many cases, a number of Middle Eastern immigrants specifically came to the Indonesia for a mission of da'wah.

One of the Muslim immigrants instrumental in the process of Islamization in the Kubu Kingdom is Syarif Idrus Alaydrus, Tuan Besar Raja Kubu. He was born on the night of Thursday 17 Ramadan 1144 (Islamic calendar) (1732 AD) in Tarim. He left his hometown and before leaving he performed istikharah prayer to God Almighty. He visited many countries on his way until it was reported that he cruised along Terentang River and then established a kingdom there.

\section{Educational method}

The educational method included all educational activities, whether formal or informal, used as a means to spread the teachings of Islam. Informal education activities were usually in the form of knowledge transfer activities between teacher and students in an informal, unplanned and unsystematic atmosphere. The formal educational activities were usually in the form of learning activities in a planned and systematic, official atmosphere.

The establishment of madrasah (Islamic school) during the reign of Syarif Saleh was an example of formal Islamization efforts. Haji Syarif Abdullah (locals usually called him Syarif Abdullah Haji) played an important role in an attempt to set up Islamic education especially in Kubu territory. Meanwhile, pengajian (Qur'an exegesis) held by Ismail Mundu in Teluk Pakedai, Kuala Karang and Pontianak was among the informal Islamization efforts.

\section{Book Writing and translation method}

The activities of book writing and translation were the most common in transmitting Islamic teachings as the way Islam was spread in the Middle East and Europe. Regarding the entry of books written in Arabic into the Kubu Kingdom, it appears to be through a variety of channels. Centuries ago, which might still go on to this day, pilgrims from the regions of the present day Indonesia in Saudi Arabia often brought home books from the Middle East. Some of the books they brought with them were later used for teaching. These books were mostly written by classical sunni scholars.

There are reports that Ismail Mundu had a collection of books that came from 
Mecca. The collections are stored at his home in Teluk Pakedai. Unfortunately these collections are not well maintained and thus almost the entire manuscripts and books were heavily damaged. Some were eaten by termites and the remaining portion is not readable. These books served as references when writing papers or books that were later printed by the Ahmadiyah, Singapore and Drukkerij Phin Min, Pontianak. It is said that when towards the end of his life, Ismail suggested that his books be handed over to the Islamic Court in Pontianak, so that they can be read and studied. If these books could not be examined, then he would suggest that they be sent to Mecca where there are many students who can read them.

In addition to the pilgrims, religious books also came through a number of publishers such as Drukkerij Phin Min Pontianak who knowingly sold and spread the religious books especially those written by Ismail Mundu. Although the activities of the translating Arabic language books have started since the 16 th century and continues to the present day, in those days these books were in the form of manuscripts circulated only among limited people. Reproduction of the manuscripts was still done by manual copying. This is understandable as at the time the printing technology had yet to develop in Indonesia. It was in the 19th century that some translation texts were published, by printing them in foreign countries, such as Singapore and Pulau Penang. Translation of works by Ismail Mundu, such as Jadual Nikah and so on were among the translation manuscript that is "touched" by the printing machine. The publication of religious books in Arabic-Malay language actually also began to flourish in the early 20th century. The author finds many of the manuscripts were published, but it was not done in mass publication because the number of publishers was limited. In addition, the economy at the time was still bad and it also had an effect on the purchasing power of the community.

\section{The Mass Media}

In addition, Islamization was also propagated through the mass media such as magazines, journals, and newspapers. In Pontianak for example a magazine called Cahaya Timur (Eastern Light) was published in 1930s. Although the coverage was not specifically on religious issues, many articles provided people with enlightenment.

The Use of print media such as magazines, journals, and newspapers had somehow shifted the traditional role of the ulama in the formation of Islamic discourse in Indonesia, and this cannot be separated from the trend of reform ideas based in Cairo at the end of the 19th century and early 20th century. Some of the communities of Jawi in Mecca became interested in the reform of 
Islam in Egypt. At the beginning of the 20th century, the magazine Al-Imam in Singapore (1906-1908) and Al-Munir in Padang (1911-1916) was published as a funnel for the reform movement in Southeast Asia. Therefore, the influence of Cairo (through Al-Manar journal) was very strong particularly on the AlImam journal. This can be seen in the structure of its editorials which was written by the Cairo alumni, as well as the substance of the pattern (Abdul Munip, 2010: 145). Later on, the process of Islamization took place peacefully either through marriage, art and literature, mysticism, and mix between the local customs and beliefs with the teachings of Islam.

\section{ULAMA AND RELIGIOUS WORKS}

Throughout the search, perhaps Ismail Mundu was the only prominent ulama with the most powerful influence in the Kubu Kingdom. This cleric came from South Sulawesi. He was born in $1287 \mathrm{H}$ (1870 AD) from the marriage of a qadiriyah tarekat (Islamic religious order) teacher with a princess named Zahra (wak Sora) originating from the region of Sungai Kakap, Kubu Raya. His father was Daeng Abdul Karim. His lineage shows that he was descended from one of the nobilities of a kingdom in South Sulawesi (Baidillah, 2008: 7).

During his youth, approximately at 7 years of age, he was student of his own uncle named Haji Muhammad ibn Haji Ali. Thanks to his intelligence, it was reported he was able to memorize the Holy Quran in seven months. Later on, his father sent Ismail Mundu to learn from one of the great scholars in his time named Haji Abdullah Ibn Salam who was popularly known as by the name Abdullah Bilawa (Baidillah, 2008: 8). This is where young Mundu Ismail acquired the basics of religious studies.

By the age of 20, Ismail Mundu performed pilgrimage and studied with Arab and Malay scholars in the Holy land. Among his teachers was Sheik Abdullah Al-Zawawi, a mufti in Mecca. In addition, he also learnt from two teachers i.e. Umar Sumbawa and Makabro, also known as Puang Lompo. From Puang Lompo, Ismail Mundu studied books containing the Islamic religious studies (Baidillah, 2008: 8). Upon completion of his studies, Ismail Mundu returned home circa $1904 \mathrm{AD} / 132 \mathrm{H}$, and lived in the Sub-district of Teluk Pakedai. This is where he practiced what he learnt from his teachers.

The efforts made by Ismail Mundu worked to straighten and improve people's religious understanding as can be seen in his works. Then, three years after that, precisely in 1907 Ismail Mundu won the trust of the Kubu Kingdom to become a mufti (see Baidillah, 2008: 13). Seen from the year of his appointment, Ismail Mundu was appointed mufti during the reign of Syarif Abbas (ruled from 1900 to 1911), the sixth King of Kubu. After Kubu Kingdom no longer 
existed and it became part of the Unitary State of the Republic of Indonesia in 1951, the first Kubu wedana (district head) whose name was Gusti Jalma held an election to occupy the office of judge. Several scholars appeared to be prospective candidates among others were Haji Ismail Mundu, Haji Abdul Syukur Badri (H Mukhlis) and Habib Husin al-Habsy. After an inquiry by observing a few terms as a judge, it was decided that Haji ismail Mundu as the person who deserved to be the judge of the Supreme Court of Kubu.

With this appointment, Ismail Mundu was responsible for a wide range of religious issues in the territory of the Kubu Kingdom. In addition to teaching his students, Ismail Mundu also wrote books. Even some of his works were written while he was in the Holy Land of Mecca. Ismail Mundu also wrote sermons to be read by a khatib (person who delivers a sermon) on every Friday and on the holy days of Islam.

During his time in Teluk Pakedai, he was visited by a number of clerics. For example, in the 1930s, Ismail Mundu got visits from Medina clerics namely Sayyid Nasir and Sayyid Abdul Sattar. They were imams (person who leads prayers) of the mosque in Medina who were once Ismail Mundu's students. Not long after that, Ismail Mundu was visited by three great scholars Sayid Hasan Japri, a mufti of Hadral Maut (Hadrami); Sayid Alwi, Yemen cleric; and Ahmad Jablawi, a cleric in a city of Egypt.

In 1937 Ismail Mundu set off to the Holy Land the third time with the family. With his departure, the Office of the mufti was submitted to Haji Hasan bin Haji Muhammad who was born in Teluk Pakedai. During his time in Mecca, Ismail Mundu briefly taught at the Haram mosque next to Safa and founded an association named Jami 'al-Tanasuh. Eleven years later, in 1948, Ismail Mundu returned home (Baidillah, 2008: 14). Considering a relatively long time being in the Holy Land and having an association with a large number of members and students, Ismail Mundu had played an important role in reforming in the network of scholars in West Borneo, even in the Malay world.

A number of his letters prove that he had correspondence with a number of scholars in the Malay and Islamic world. First, a letter of recognition of the extent of Ismail Mundu's knowledge presented by Alwi bin Tahir bin Abdullah al-Haddad Alwi as the mufti of the Kingdom of Johor Malaysia on 7 Rabiul Awal 1358 H. Second, a letter of commendation over the Ismail Mundu's accuracy in writing books sent by Abbas bin Muhammad Taha, head of the qadi-qadi (qadi qudat official) of Singapore on 7 Rabiul Awal 1358 H. Third, a letter sent by Muhammad al-Zawawi from Mecca dated 15 Safar $1340 \mathrm{H}$.

The tradition of giving diplomas to students was one of the efforts related 
to the transmission of knowledge, which not only happened in the Middle East but also in Indonesia, including in the Kubu Kingdom. In one of the manuscripts, it is described that Ismail Mundu gave diplomas only to his students who were qualified to continue his teachings. After a careful search, there are more than 29 works written Ismail Mundu. His works were largely the original texts in the form of manuscripts and some of them were printed, especially by Al-Matba'ah al-Ahmadiyah Singapore. The reviews of his books will be described as follows.

\section{A collection of stories of isra 'mi'raj.}

To facilitate the understanding and to make the lessons interesting, Ismail Mundu divided the story of isra 'mi'raj (ascension of Prophet Muhammad) into several parts (juzu'). There are 16 (sixteen) juz of stories that explain the stages of isra mi'raj. His works are described briefly as follows: The first juzu'. In this first manuscript, Mundu describes the identity of the author and the purpose of this little manuscript writing. "The story of sahibu al-taji fi alisra'wa al-mi'raj translated by al-'alim al-fadil Syekh Ismail bin Abdul Karim al-Bugisi al-Puntiani is divided into sixteen juzu' so kids who want to read it on the eve of the glorious ascension." Mundu also explains about the time and the event of isra 'mi'raj, which happened with the spirit and the body at once.

The second juzu'. In this part, the Prophet traveled by riding a buraq, a whitecolored animal larger than a mule and smaller than a donkey. Upon arriving at a village, the Prophet performed two rakaiah (unit) of prayer. The third juzu'. The Prophet is said to continue the journey and had to stop several times one of which was at the hill of Tursina, the place where Moses received the revelation. Then he performed prayer in the place where Prophet Isa Ibn Maryam was born. It was narrated about people sowing the seeds and later on that same day reaping the results. In the next part, the Prophet smelt fragrance and questioned where it was coming from. Then Gabriel explained that the source of the fragrance was Siti Masyitah, the girl who combed the hair of the Pharaoh's daughter.

The sixth juzu'. This section deals with the Prophet entering the Baitul Maqdis mosque performed tahiyyat al-masjid prayer. Then came the angels who filled up the mosque. The Prophet was asked to become the imam, and performed two raka'ah of prayer with them. Later, the Prophet was offered by Gabriel two or three different kinds of drinks. The Prophet was asked to select one of the drinks. The seventh juzu'. This section describes the stairs in the event of ascension and levels of heaven that the Prophet ascended through. The eighth juzu'. This part tells about Prophet Muhammad meeting Prophet Adam. There 
are two doors to the right and the left of Adam. When he looks at the right side, he is happy because his descendants are in heaven, and when he looks at the left he weeps because his descendants are in hell. Then the Prophet ascended to the second heaven and met Prophet Jesus and Yahya. Then continued up into the third heaven and met Prophet Joseph.

The tenth juzu'. This section describes Prophet Muhammad and Gabriel ascending to the seventh heaven. Here the Prophet met Prophet Abraham who was sitting near the door of heaven on a chair made of gold along with a number of people from his own family. The Prophet greeted him. During the meeting, Prophet Abraham gave advice to Prophet Muhammad. On the other part there is a dialogue between Gabriel and the Prophet (peace be upon him) about a group of people having a face like white paper but some were dullfaced.

The twelfth juzu'. In this section the Prophet tells a story about seeing a person near arsy, but it was not clear whether it was a prophet or an nngel. Then Gabriel explained that the man was a human being that who constantly wet his lips to praise God, his heart was always close to the mosque, and he never said rude words to his parents. At the end of the section it is said that the Prophet received command of prayer as many as 50 (fifty) times a day. Then the Prophet met with Abraham, but no dialogue occurred between the two. The thirteenth juzu'. It is described in this section the Prophet ( $p b u h$ ) met Moses. This is where a dialogue was made between the two. In the next section, the Prophet finally got the command of prayer as many as 5 (five) times. But Moses continued to suggest that the Prophet (pbuh) go up to God in order to reduce the number of salat. The fourteenth juzu'. In this part, the Prophet descended onto the earth. On the way home, he said to Gabriel that everyone prayed for him and smiled at him except one. Then Gabriel replied that it was the Angel of Malik, the guardian of hell. Since he was created by God, he had never smiled. Then, by dawn the Prophet was already in Mecca among his companions. The next section mentions that a lot of people don't believe the news delivered the Prophet.

This section describes the difference of opinion between the faithful and among the Quraish in response to the event of isra 'mi'raj. The pagan Quraysh thought that the Prophet had told a big lie. Some of the questions were asked to attack the Prophet such as characteristics and number of columns of bait almaqdis. But these questions could be answered by the Prophet precisely and satisfactorily. However, doubt persists. In the middle of the dialog, Abu Bakr flatly stated that what was delivered by the Prophet is a truth. The sixteenth khatimah mi'raj: Miraj juzu'. At the beginning of this section, Ismail Mundu 
mentions the virtue of commemorating the birthday of the Prophet. In the closing section, Mundu reiterated the importance of reading the story of the Mawlid of the Prophet, peace be upon him. "I expect all that are present in this council to celebrate the honor of our Prophet by reading the Mawlid everywhere ... hopefully Allah the Most High will bestow upon us great rewards ... and we all will get safaat at the Last Judgment".

\section{Collection of Sermons}

The next works of Ismail Mundu is a collection of sermons that he arranged by interests and under certain conditions. The number reached 14. It is written in Arabic, but accompanied by the translation of the Malay language. The following is a brief overview of his sermon manuscripts.

Sermon of the month of Muharram. In this manuscript, Ismail Mundu narrated the events of Karbala in which Sayyidina Husien ibn Ali Ibn Abi Talib was killed. Other parts also contain advice for fasting in the month of Muharram.

Sermon of the month of Safar. Ismail Mundu wrote about the importance of remembering death and staying away from the greedy actions. In the next section, he wrote down the events of the death of the Prophet Muhammad and the compassion enveloping the departure of the best being in the universe.

Sermon of the month of Jumadil Awal. In the early part of this manuscript, it is written: "This is the sermon of the month of Jumadil Awal, and it may also be given in other months." This manuscript describes the sanctions addressed to people who leave the prayer.

Sermon of the month of Jumadil Akhir. At the beginning of the manuscript it is written: "This is the sermon of the month of Jumadil Akhir, and it may also be given in other months." This sermon contains warnings from Ismail Mundu about actions that cause people to get into perdition. He cites the hadith that the Prophet cried because he predicted that there will come a time when rulers are unjust, traders dishonest, and drinking liquor becomes a habit, cohabitation occurs everywhere, and so forth. Then he comes close with recommendations for immediate repentance.

Sermon of the month of Rajab. This manuscript contains advice to always keep away from prohibited deeds and fill life with good conducts.

Sermon of the Month of Dzulqaidah. This paper describes the importance of remembering the death. Every living creature will end with death. And in the Day of Judgment, every person will be collected at the Mahsyar to be brought to account. One will not be allowed to move on a day of judgment before being 
asked four things: what his life is spent for, what his physical health is used for, what has he done, and where his wealth comes from and what he spends it for. Sermon of the months of Hajj. This manuscript describes the way of performing pilgrimage and the virtue of each mandatory pillar the Hajj. It also contains the virtue of those who perform the Hajj. At the end of the sermon, Mundu recommends that the month of Dzulhijjah be filled with good deeds.

Sermon of the Hajj Holy Day. This sermon talks about the virtue of the city of Mecca.

Sermon for building a new mosque. The original manuscript title reads "This sermon shall be read upon completion of a mosque or renovation of a mosque, and there is also a final sermon." In this sermon Mundu talks about the motivation for building a new mosque and a number of deeds that shall be rewarded eternally even though the person has died.

Sermon of the solar eclipse. The content of this manuscript discusses the solar eclipse prayer. Mundu explains how this eclipse prayer should be performed in detail, ranging from intention to greetings (beginning to end).

Sermon of the lunar eclipse. In the early part of this manuscript it is written "This is an initial sermon of the lunar eclipse and there is also a final." The entire text of this sermon is in Arabic except for a little description in Malay.

Sermon of Marriage. This manuscript contains readings and prayers which must be read in a matrimonial ceremony.

Sermon for each Friday. This manuscript contains guidelines for conducting Friday prayers such as how to praise God and to read salawat upon the Prophet (pbuh).

\section{Zikir Tawhidiyah}

This booklet was printed at Matba'ah Al-Sayyid Ali Alaydrus, Keramat 38, Jakarta. This type of printing is still in the form of blue print (lithograph). One version of the manuscript obtained by the author has been transliterated to Malay by Riva'i Abbas. With the transliteration, this manuscript expanded its spread not only among Ismail Mundu's students but also to the various areas and West Kalimantan. This manuscript achieved wide circulation since it was printed outside of West Kalimantan, i.e., Batavia (Jakarta).

\section{Kitab Mukhtasar al-Mannan 'ala 'Aqidat al-Rahman}

This 20-page book was printed at Matba'ah Al-Sayyid Ali Alaydrus Keramat 38 Jakarta. This type of printing is still in the form of blue print (lithograph). In general, it contains the teachings about the 20 attributes which are divided 
into a number of attributes of God, which are the attributes of obligation, impossibility, probability for God. In the next section, it also outlines the lessons about the nature of the Prophet which is divided into the nature of obligation, impossibility and probability. At the end of the book, Mundu wrote: “... I have finished writing this book, Mukhtasar al-Mannan 'ala " Aqidat al-Rahman on Thursday the 25th of the month of Safar 1375 Hijrah of the Prophet ..." (p. 20-21)

\section{Kitab Mukhtasar Aqaid}

The book was completed in Teluk Pakedai on Friday, at 5 p.m., 18 Rajab 1351. It contains theological lessons for children to memorize and was printed by Annashar \& co. of Pontianak. The information about the book is obtained through the writings of Datok Abang Zahry Abdullah al-Ambawi and M. Natsir.

\section{Faidah Istighfar Rajab}

The original title of the book is: "Faidah Istighfar Rajab translated Guru Haji Ismail Mufti of the Kubu Kingdom, with Malay translation accompanying it". The book obtained by the research team is in the form of photocopy and printed by Drukkerij Phin Min Pontianak 1417-24. The book consists of 17 pages, without any information on the date of writing, and on the back there is a text that reads: "Haji Ismail, Mufti of the Kubu Kingdom has presented a diploma to anyone who holds this book", as well as his photograph attachment.

\section{Jaduwal al-Nikah}

On the cover of this manuscript, it is written: "this is the book called Jaduwal Nikah, questions and answers in the Malay language compiled and translated by al-Haqir Haji Ismail bin Abdul Karim, Mufti of the Kubu Kingdom ghafara Allah lahu wa liwalidaihi wa li jami'i al-muslimin." The book was printed by the Printing Office and Bookstore al-Sayyid Ali al-Salibiyah Alaydrus, Keramat no. 38 Batavia, Sentrum telepon 1655, Wiltffriden.

This book consists of 32 pages. Broadly speaking, this book contains a discussion of the notion of marriage and the law, causes of lian, requirements for a guardian of marriage, requirements for ijab qabul, name of the female guardian, requirements for the tahkim guardian and iddah for contemporaries. Two pages of which contain advertising of the printing of al-Sayyid Ali Alaydrus Batavia Sentrum. 


\section{Majmu' al-Mirats fi hukmi al-Faraid}

This manuscript serves as a guide for the division of inheritance especially for beginners. At the beginning of the manuscript, it is written: "This book called Majmu' al-Mirats fi hukm al-Faraid, Malay translation, with a schedule so as to make it easy to figure out the problem for the beginners, a an heirloom and asabah, translated by al-Shaykh Ismail ibn Abdul Karim, the mufti of Kubu Kingdom al-Bugisi al-Pontiani jaza Allah taiala khairan wa ajra lahu ajran amin tammun.

One of the unique religious works is a book written by Syarif Saleh. Its uniqueness lies in its author, who was none other than the eighth King of Kubu. The book is entitled Nashihat al-Zaman. The purpose of writing this book is explained on the front page. Syarif Saleh also wrote another book entitled Nashihat al-Awlad. However, the information on this book can only be obtained from an Arabic-Malay manuscript written by Syarif Saleh himself.

\section{RELIGIOUS INSTITUTIONS}

As the Islamic Kingdom, Kubu had several religious institutions that were part of the Kingdom, such as the office of the mufti held by Ismail Mundu. No description that mentions the structure of the office like that of the Kingdom of Sambas. Sambas explicitly mentions religious offices ranging from maharaja imam, imam maharaja, khatib, penghulu, lebai, and modim. Each religious office has its respective duties and functions. The Kubu Kingdom was different from Sambas Kingdom in which the office of the mufti included all religious duties and functions in the territory of the Kingdom. This among other things was caused by the smaller number of population of the Kubu Kingdom as compared to that of Sambas.

To deal with the religious affairs, Ismail Mundu appointed some of his students to become imam and granted them the right to marry. This designation is usually accompanied by a diploma (interview with Haji Riva'i, Sept 21, 2012) According to Sood Ja'far (interviewed on Sept 27, 2012) marriage certificates before Japanese occupation were the yellow piece of paper written in ArabicMalay issued by the Kingdom with the King's stamp seal. Based on historical data, the office of $m u f t i$ of the Kubu Kingdom was only assumed by two people, namely Ismail Mundu and Haji Hasan.

In addition to the office of mufti, the mosque also played an important role in the teaching of Islam in the Kingdom. Although no definite data found regarding the construction of the mosque, it was obvious that it had stood there not long after the sultan built capital. This Royal Mosque site can still be found today. Even though it has undergone renovation several times, the 
original architecture of the building has not changed.

In addition to the Royal mosque located in Kubu, Ismail Mundu also built another mosque in Teluk Pakedai. The mosque is called the Nashrullah mosque or better known as Masjid Batu (the rock mosque) because the main building materials are rock (concrete). While at that time, most buildings only used material from wood. The mosque had become a place for Ismail Mundu to teach his students. In his instruction process, Mundu used the following places:

To date the Nasrullah mosque has undergone three renovations. The first Mosque, when built by Ismail Mundu, has the following words (ma sya Allahu kana, wa man lam yasya' lam yakun') at the entrance gate of the mosque. The renovation was financed by a benefactor named Haji Doing who lived on Gg. Camar, Pontianak (interview with Haji Riva'i, Oct 10, 2012).

There is no data with regard to the establishment of the formal education madrasah (Islamic school) in this era. In 1936, however, a madrasah, was founded especially when the Kubu King Syarif Saleh was in power. All the lessons were about the Qur'an and the Arabic language basics. Haji Syarif Abdullah was assigned to teach here. The madrasa was originally reserved for the children of the officials of the Kingdom. Thanks to the influence and the number of pupils, the name Syarif Abdullah is remembered until the 60 's in Kubu.

The sixth King of Kubu, Syarif Saleh, always celebrated his birthday which was on $11^{\text {th }}$ day of Dzulhijjah. During he usually held mass marriages that took place in the Palace. All costs were paid by the King and the entire citizens of the Kingdom starting from Kubu, Padang Tikar, Terentang and Teluk Pakedai were invited. Another thing King Syarif Saleh did was that he always invited a Sheik from the Middle East every Ramadan to teach Islam. One of the clerics invited was Syekh Taisir. During his visit in Kubu, the Sheik was lodged at the house of son-in-law of the King named Syarif Yusuf. For ease of communication, a translator was employed (interview with Sood Ja'far, Sept 27, 2012).

\section{CONCLUSION}

The process of entry and spread of Islam in the Kubu Kingdom is unique. Its uniqueness lies in the integration of Islam which directly came from the Middle East with the locals. There are a number of pathways that encourage the entry and development of Islam in the Kubu Kingdom among other things: first, through Dawah by Muslim immigrants; Second, through education. Third, through writing and translation of books. Fourth, through the mass media. 
Works by Islamic religious scholars in the Kubu Kingdom have contributed to the dynamics of the development of Islam in the southern region of West Kalimantan. There are at least three aspects of influence from the inception of the religious works, among others: first, the scientific aspect; these works have intensified the spirit of Islamic scholarship in the Kingdom. Second, the social aspect of the religious works has managed to straighten out the practices of Islam; and third, the political aspect; it is undeniable that politically religious works have strengthened the position of Islam in the region. These religious works were not only produced by scholars, but also by the Kings of Kubu.

\section{REFERENCES}

H. Riva'ai bin H. Abbas. 1984. Riwayat Hidup Al-Mukarram al-Hajj al-Fadhil Ismail Mundu. naskah

Irwin, Graham. 1986. Borneo Abad Kesembilan Belas: Kajian Mengenai Persaingan Diplomatik. Kuala Lumpur: Dewan Bahasa dan Pustaka Kementerian Pelajaran Malaysia

Ismail Mundu. Jadwal al-Nikah. Percetakan Singapura

Jadwal al-Nikah. Percetakan Batavia

Kumpulan Khutbah Jilid 1-14. Unpublished Manuscript

. Miraj Juzu' yang Pertama. Unpublished Manuscript

Mi'raj Juzu' yang Kedua. Unpublished Manuscript

. Miraj Juzu' yang Ketiga. Unpublished Manuscript

Mi'raj Juzu' yang Keempat. Unpublished Manuscript

Mi'raj Juzu' yangKelima. Unpublished Manuscript

Mi'raj Juzu' yangKeenam. Unpublished Manuscript

Mi'raj Juzu' yangKetujuh. Unpublished Manuscript

Miraj Juzu' yangKedelapan. Unpublished Manuscript

Miraj Juzu' yangKesembilan. Unpublished Manuscript

. Mi'raj Juzu' yangKesepuluh. Unpublished Manuscript

Mi'raj Juzu' yangKesebelas. Unpublished Manuscript

Mi'raj Juzu' yang Keduabelas. Unpublished Manuscript

Miraj Juzu' yang Ketigabelas. Unpublished Manuscript

Miraj Juzu' yang Keempatbelas. Unpublished Manuscript

Miraj Juzu' yang Kelimabelas. Unpublished Manuscript

Miraj Juzu' yang Keenambelas. Unpublished Manuscript

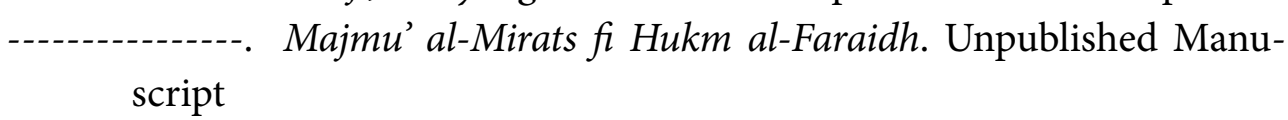

Zikir Tauhidiyah. Unpublished Manuscript

Mukhtatasar al-Mannan fi Ibadat al-Rahman. Percetakan Sin-

gapura. 
Lisyawati Nurcahyani. 1997. Pendataan Sejarah Kerajaan Kubu. Balai Kajian Sejarah dan nilai Tradisional. Laporan Penelitian

Mahmud Yunus. 1962. Sejarah Pendidikan Islam di Indonesia. Jakarta: Sumber Widya

Pasifikus Ahok, dkk. 1983. Sejarah Pendidikan Daerah Kalimantan Barat. Pontianak: Dapartemen Pendidikan dan Kebudayaan Kalimantan Barat

Pasifikus Ahok, dkk. 1992. Sejarah Revolusi Kemerdekaan (1945-1949) Daerah Kalimantan Barat. Pontianak: Dapartemen Pendidikan dan Kebudayaan Kalimantan Barat

Pijper, G.F., 1984. Beberapa Studi tentang Sejarah Islam di Indonesia 19001950. diterjemahkan oleh Tudjimah. Jakarta: UI Press

Sendam XII/ Tanjungpura. 1970. Sejarah Kodam XII/ Tanjoengpoera Berjoeang. Pontianak: Sendam XII

Soedarto, dkk. 1979. Sejarah Kebangkitan Nasional Daerah Kalimantan Barat. Jakarta: Departemen dan Kebudayaan

Soedarto. 1986. Deskripsi Peta Sejarah Peta Kalimantan Bara. Pontianak: Balai kajian Sejarah dan Nilai Tradisional

Soedarto. 1986. Peta Sejarah Peta Kalimantan Bara. Pontianak: Balai kajian Sejarah dan Nilai Tradisional

Sy. Djunaidy. 1997. Menyingkap Sejarah Kerajaan Kubu. Naskah Ketikan Manual

Sy. Saleh. Nasihat al-Zaman. Batavia: Kantor Cetak dan Toko Kitab Sayyid Ali Alaydrus

Veth. P.J. 1584. Borneo's Wester-Afdeeling.

Victor T. King. 1993. The Peoples of Borneo. Oxford UK dan Cambridge USA: Blackwell

Yoseph. 1996. Selayang Pandang Kerajaan Kubu. Unpublished Manuscript 
